\title{
A comparative study of pentoxifylline effects in adult and aged rats submitted to lung dysfunction by thermal injury ${ }^{1}$
}

\author{
Bianca Trovello Ramallo, Elizete Lourenço", Renata Harumi Cruz ${ }^{\mathrm{III}}$, Jacqueline Camargo Almeida ${ }^{\mathrm{IV}}$, Murched Omar Taha

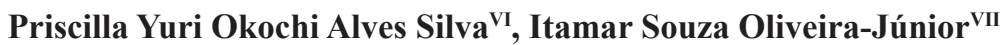

\begin{abstract}
IFellow PhD degree, Cardiovascular Postgraduate Program, Department of Surgery, UNIFESP, Sao Paulo-SP, Brazil. Design of the study, acquisition and interpretation of data, statistical analysis, involved with technical procedures.

IIGraduate student, Scientific Initiation, Division of Anesthesiology, Pain and Intensive Therapy, UNIFESP, Sao Paulo-SP, Brazil. Animal anesthesia, acquisition and interpretation of data, analysis of the determination of malondialdehyde.

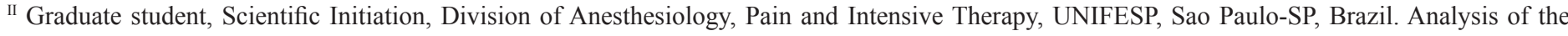
determination of total protein and myeloperoxidase activity, acquisition and interpretation of data.

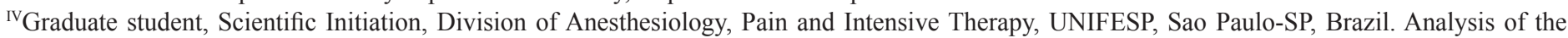
determination of inflammatory mediators, acquisition and interpretation of data.

${ }^{\mathrm{V}} \mathrm{PhD}$, Associate Professor, Surgical Techniques and Experimental Surgery Division, Surgery Department, UNIFESP, Sao Paulo-SP, Brazil. Critical revision and final approval of the manuscript.

${ }^{\mathrm{VI}}$ Graduate student, Scientific Initiation, Division of Anesthesiology, Pain and Intensive Therapy, UNIFESP, Sao Paulo-SP, Brazil. Histological analysis, acquisition and interpretation of data.

VII Associate Professor, Division of Anesthesiology, Pain and Intensive Therapy, UNIFESP, Sao Paulo-SP, Brazil. Supervisor, critical revision and final approval of the manuscript.
\end{abstract}

\footnotetext{
ABSTRACT

PURPOSE: To investigate the protective effects of pentoxifylline against lung injury observed after dorsal scald in aged animals.

METHODS: Adult (eight months old) and aged (20 months old) rats were subjected to thermal injury or sham procedure. The six hours post-trauma animals received pentoxifylline and after 24 hours were euthanatized and lung tissue samples collectedted. The bronchoalveolar lavage fluid was evaluated for total protein content and tumor necrosis factor-alpha cytokine. Malondialdehyde and myeloperoxidase activety in the lung homogenate were measured and a histological lung examination was undertaken.

RESULTS: Burn injury induced oxidative stress in lung homogenate was higher in elderly-burned rats compared to adult-burned rats $(\mathrm{p}<0.001)$. Total protein and cytokine in bronchoalveolar lavage increased in the elderly-burned group when compared to the adultburned group $(\mathrm{p}<0.001)$. All parameters decreased in bolth groups treated with pentoxifylline $(\mathrm{p}<0.05)$.

CONCLUSIONS: The injury was augmented in elderly rats when compared to adult rats. Damage was reduced with the use of pentoxifylline, however further studies are needed to evaluate the dose-response of the drug.

Key words: Burns. Aging. Lung Injury. Cytokines. Pentoxifylline. Rats.
} 


\section{Introduction}

According to the American Burn Association indicates that there have been more than 163,000 burn cases over the last ten years ${ }^{1}$.

Aged individuals who suffer this type of injury seem to have greater mortality than those who are younger. For example, a moderate size burn covering $20 \%$ of the total body surface area (TBSA) is associated with a mortality rate of only $5.5 \%$ in healthy young adult patients, elderly patients, on the other hand, with the same burn size have a mortality of $75 \%{ }^{2}$.

The lungs are important organ in the inflammatory response process in burned patients, due to their great capacity in producing inflammatory mediators and radical oxygen species. Pneumocyts cells may be activated by various substances including radical oxygen species, vasodilatators and chemistry mediators. These substances, in turn, increase the inflammatory response with edemas, surfactant alterations, bronchial obstruction and hypoxia. These substances also contribute to the systemic inflammatory response syndrome development in the burned patients when passing through systemic blood ${ }^{3}$.

For five decades, it has been recognized that severe burn injury may cause marked alterations in immune functions, resulting in life-threatening systemic infections, sepsis, multiple organ failure, and even death. Extensive and deep burns have widespread and profound impacts on various cells and molecules of the immune system. Of the many factors contributing to the increased lethality of injury in elderly populations, one is the diminished function of both the innate and adaptive immune systems. Specific age-related alterations in cells of adaptive immunity have been well-established ${ }^{4}$. Abnormal functioning in components of innate immunity has also been documented in aged subjects ${ }^{5}$. Furthermore, a hyper-inflammatory state, referred to as "inflamm-aging", highlighted by elevated circulation levels of pro-inflammatory factors (interleukin [IL]-1 $\beta$, IL-6, tumor necrosis factor [TNF]-alpha, and prostaglandin $\mathrm{E}_{2}$ ) are associated with advanced age ${ }^{6}$. The pathogenic mechanisms in severely burned patients are not yet fully understood, although it is clear that neutrophil accumulation in the lung is involved ${ }^{7}$.

The neutrophil recruitment to the lung after thermal injury has been reported by various laboratories ${ }^{8,9}$. It should also be noted that the experimental approach used in this study complements the clinical picture observed in multiple organ failure (MOF) syndrome, which generally originates in the lungs.

Pentoxifylline (PTX), a methylxanthine derivative known for many years for its haemorheological properties, has proven to be a potent inhibitor of TNF production. The potential local effects are important for acute lung injury manifestation by inflammatory mediators and oxygen-free radical activation ${ }^{10}$.

We used our previous experience with pentoxifylline to study and compare the cytokine and myeloperoxidase activity, malondialdehyde, total protein and histological analyzes in adult and elderly animals submitted to thermal burn and treated with pentoxifylline.

\section{Methods}

\section{Experimental animals and research design}

All animal care and manipulations were approved by the Institutional Research Committee of the Federal University of Sao Paulo (1156/08), in accordance with National Institute of Health (NIH) Guidelines Regarding Animal Experimentation.

Adults (male; eight month) and aged (male; 20 month) Wistar rats (Rattus norvegicus albinus), from the Federal University of São Paulo (UNIFESP, SP, Brazil) were housed in the vivarium under controlled temperature $\left(22^{\circ} \mathrm{C}\right)$ and photoperiod (12-hour light/dark period) with free access to water and food. In order to avoid interference factors related to circadian rhythms, all studies were performed between 8 and 10 am. A 2-wk acclimatization period was allowed before experimental manipulations were initiated. In this study male rats were chosen due to manipulation and hormonal conditions.

\section{Thermal injury}

Briefly, animals were anesthetized intraperitoneally (ip) with sodium pentobarbital $(50 \mathrm{mg} / \mathrm{kg}$; Thionembutal, Abbott, SP, Brazil). The hair was shaved from the back and the area was treated with a depilatory agent. Each animal was placed in a wooden container with an opening that exposed approximately $30 \%$ of the TBSA. The back burn was produced by immersing the back of the animal through the template into $95^{\circ} \mathrm{C}$ boiling water for 10 seconds; this procedure produced a third-degree standard scalding. The sham group (unburned animals) was immersed in $22^{\circ} \mathrm{C}$ for $10 \mathrm{~s}$. Animals were given $4 \mathrm{~mL} / \mathrm{kg}$ of lactate ringer ip for resuscitation after of procedure. Animals were then placed in individual cages and allowed to recover under a warming lamp for prevent hypothermia. All rats also received $0.3 \mathrm{mg} / \mathrm{kg}$ of buprenorphine (subcutaneous).

Animals were divided in six groups ( $\mathrm{n}=7$ per group): ASham, adult unburned; ESham, elderly unburned; AB, adult 
burned; EB, elderly burned; AB+PTX, adult burned and PTXtreated; EB+PTX, elderly burned and PTX-treated.

\section{Pentoxifylline administration}

The animals of the drug groups received $25 \mathrm{mg} / \mathrm{kg}$ with PTX by ip injection (FARMASA, SP, Brazil) 6 hour post-injury. The other groups received sterile saline solution in the same volume of the PTX groups.

\section{Bronchoalveolar lavage (BAL)}

At the end of experiment, all animals were euthanized (ip doses of $1 \mathrm{~mL} / 100 \mathrm{~g}$ body weight; T-61 Euthanasia Solution, Schering-Plough, SP, Brazil). A sternotomy was performed and the lungs and structures were removed. The left main bronchus was cannulated and secured. Saline solution $\left(15 \mathrm{~mL}\right.$, at $\left.4^{\circ} \mathrm{C}\right)$ was then injected as three aliquots of $5 \mathrm{~mL}$ each. Each aliquot was injected quickly and then withdrawn slowly three times to obtain the BAL specimen. Combined aliquots of BAL fluid were spun at $1,000 \mathrm{x} g$ for 10 minutes to remove the cells and the cell pellet was resuspended in $1 \mathrm{~mL}$ of saline.

Total protein content: The total protein in BAL was performed using a Lowry et al. ${ }^{11}$ method.

Pro-inflammatory cytokine: TNF-alpha was analyzed in the BAL using commercially available enzyme-linked immunosorbent assay [ELISA] kits (R\&D Systems, MN, USA; range for $5 \mathrm{pg} / \mathrm{mL}$ to $800 \mathrm{pg} / \mathrm{mL}$ ). The absorbance was measured using a microplate reader (wavelength $450 \mathrm{~nm}$; ELx800; Bio-Tek Instrument, VT, USA).

Determination of lipid derived oxidation products (malondialdehyde [MDA]): The lipid peroxide levels in the lung were measured in the upper right lobe by thiobarbituric acid (TBA) reaction according to Yagi and Okhawa et al. ${ }^{12,13}$. Absorbance was recorded at $532 \mathrm{~nm}$ and compared with that obtained from MDA standards.

Myeloperoxidase (MPO) activity: The MPO activity was assessed in the lung tissue using a procedure described by Hillegass et al. ${ }^{14}$. Lung tissue samples were homogenised in 50 $\mathrm{mM}$ potassium phosphate buffer ( $\mathrm{PB}, \mathrm{pH}$ 6.0) and centrifuged at 3,000 x $\mathrm{g}(30 \mathrm{~min})$; the pellets were suspended in $50 \mathrm{mM} \mathrm{PB}$ containing $0.5 \%$ hexadecyltrimethylammonium bromide (SigmaAldrich, SP, Brazil). After three freeze-and-thaw cycles with sonication between cycles, the samples were then centrifuged at $3.000 \mathrm{x} g$ for $30 \mathrm{~min}$. Aliquots $(0.3 \mathrm{~mL})$ were added to $2.3 \mathrm{~mL}$ of reaction mixture containing $50 \mathrm{mM} \mathrm{PB}$, o-dianisidine (SigmaAldrich, SP, Brazil) and $20 \mathrm{mM} \mathrm{H}_{2} \mathrm{O}_{2}$ solution. One unit of enzyme activity was defined as the amount of MPO present that caused a change in the absorbance, measured at $460 \mathrm{~nm}$.

Morphology: The left lung was formalin-inflated and -fixed. The tissue was subsequently paraffin-embedded and 4- $\mu \mathrm{m}$ sections were stained with hematoxylin and eosin (HE). Sections were evaluated using light microscopy coupled to a video camera (Axiolab Standart 2.0 and AxionCam, Zeiss, Jena, Germany, respectively) and examined by a blinded pathologist. Two nonadjacent sections were examined from each animal.

\section{Statistical analyses}

Results were expressed as a mean \pm standard deviation $(\mathrm{m} \pm \mathrm{SD})$. Values were compared between groups using an analysis of variance (ANOVA) followed by Tukey's multiple comparison tests, of SPSS 11.0 statistical software (SPSS Inc. Software, IL, USA). Values of $\mathrm{p}<0.05$ were considered statistically significant.

\section{Results}

The animals of all groups, burned and burned treated with PTX, differ statistically when compared to their respective Sham counterparts.

\section{Total protein}

Animals submitted to thermal injury showed an increased protein content (Figure 1). A greater increase was observed in the EB group when compared to the AB group $(p=0.001)$. A smaller increase was observed between the adult and elderly burned group when compared to the respective counterpart treated with pentoxifylline $(\mathrm{p}=0.001)$. 


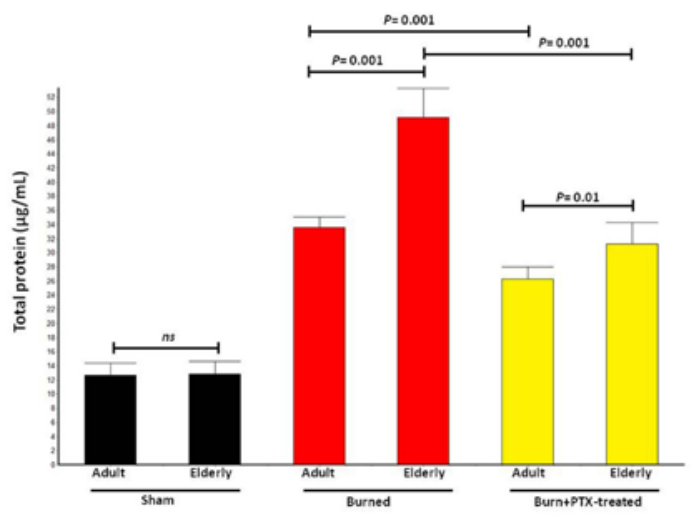

FIGURE 1: Total protein content of the post-burn groups were significantly greather then the values of the Sham groups $(p=0.001)$. The protein content was significantly reduced in the burn groups post-treated with PTX when compared with the respective non-treated burned groups $(\mathrm{p}=0.001)$.

\section{Tumor necrosis factor-alpha (TNF-alpha)}

The TNF-alpha level in BAL (Figure 2) was significantly higher in the elderly burned $(239 \pm 10.4 \mathrm{pg} / \mathrm{mL})$ group than that of the adult groups $(173 \pm 2.8 \mathrm{pg} / \mathrm{mL})$. The TNF-alpha decreased in the animals treated with PTX (adult: $56 \pm 3.6 \mathrm{pg} / \mathrm{mL}$ and elderly: $85 \pm 3.4 \mathrm{pg} / \mathrm{mL})$.

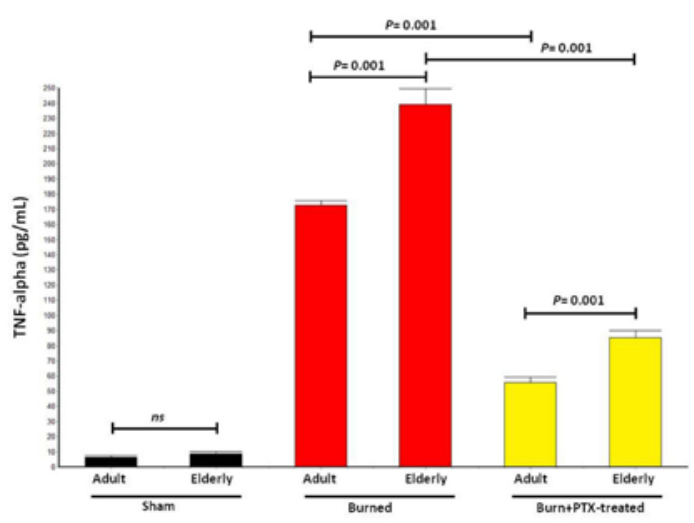

FIGURE 2 - The TNF-alpha levels of the post-burn groups were significantly higher than the values of the Sham groups $(p=0.001)$. The TNF-alpha was reduced significantly in the burn groups post-treated with PTX when compared with respective burned groups non-treated $(\mathrm{p}=$ $0.001)$.

\section{Malondialdehyde (TBARS-MDA) levels}

The levels of lipid peroxidation (Figure 3) were significantly higher in the adult $(4.7 \pm 0.1 \mathrm{nmol} / \mathrm{mg}$-protein) and elderly non-treated groups $(5.5 \pm 0.09 \mathrm{nmol} / \mathrm{mg}$-protein $)$ when compared with the PTX-treated groups under the same conditions (adult: $3.3 \pm 0.2 \mathrm{nmol} / \mathrm{mg}$-protein and elderly: $3.9 \pm 0.1 \mathrm{nmol} / \mathrm{mg}$ protein; $\mathrm{p}=0.001)$.

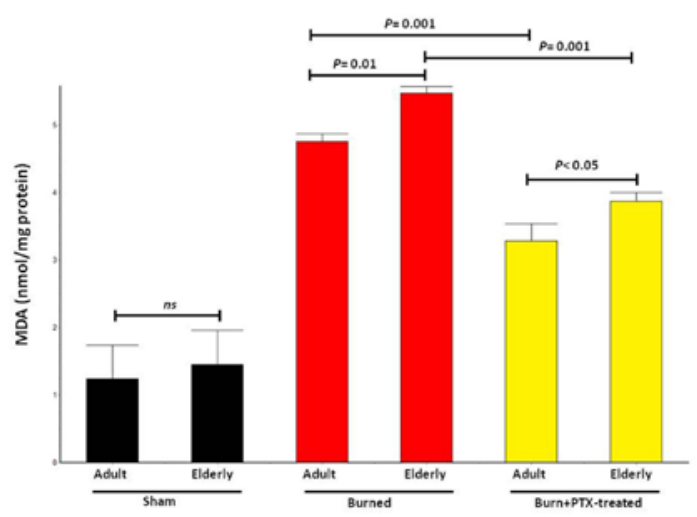

FIGURE 3 - The TBARS-MDA levels, which show the lipid peroxide levels, of the post-burn groups was significantly higher than the values of the Sham groups $(p=0.001)$. The TBARS-MDA was reduced significantly reduced in the post-treated burn groups with PTX when compared with the no-treated respective burned groups $(p=0.001)$.

\section{Myeloperoxidase (MPO) activity}

MPO activity (Figure 4) was found to be significantly reduced in the burned adult and elderly group treated with PTX $(18 \pm 1.3 \mathrm{U} / \mathrm{g}$ tissue and $23 \pm 3.0 \mathrm{U} / \mathrm{g}$ tissue, respectively) when compared to the adult and elderly burned only $(27 \pm 1.9 \mathrm{U} / \mathrm{g}$ tissue and $35 \pm 2.8 \mathrm{U} / \mathrm{g}$ tissue, respectively). In the elderly untreated burned group the MPO activity was increased when compared to the adult group $(\mathrm{p}=0.001)$.

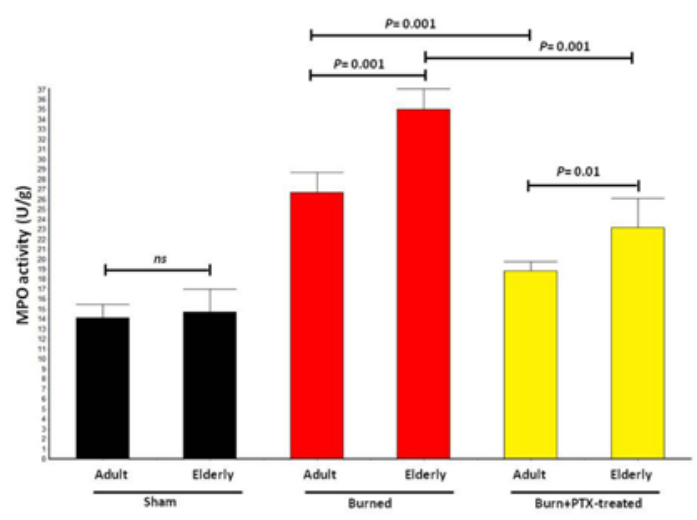

FIGURE 4 - Myeloperoxidase (MPO) activity was measured in lung tissue in rats with a $30 \%$ body surface area burn. The burned adult and elderly groups had higher MPO activity compared to the respective Sham $(\mathrm{p}=0.001)$ and PTX-treated $(\mathrm{p}=0.001)$ groups.

\section{Histological analyses}

Histologic analysis of the lung revealed a moderate degree of interstitial edema and septae neutrophil in the burned adult group. On the other hand, in the burned elderly group the effects were severe and presented congestion areas. In the animals 
treated with PTX these parameters were reduced (Figure 5).

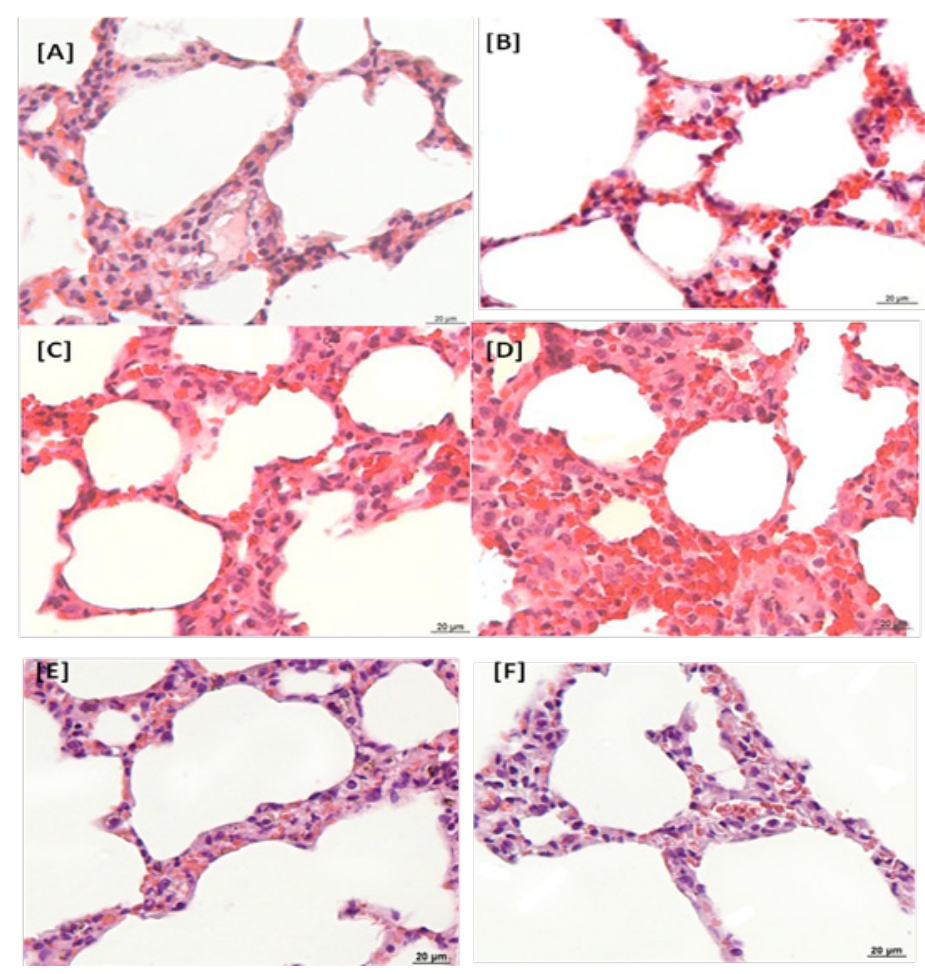

FIGURE 5 - Histological lung tissue evaluation in animals submitted to dorsal scald. A- adult Sham; B- elderly Sham; C- adult burned; D- elderly burned; E-adult PTX-treated; F- elderly PTX-treated. In the adult burned the lung presented moderate injury with edema and dilated septae. In the elderly burned the lung presented severe edema, dilated septae and more congestion areas and PMN cells in the alveolar wall. In the PTX-treated groups these alterations were much less evident.

\section{Discussion}

In this study, we analyzed the effects of aging and PTXtreatment on the lung inflammatory response in a model of dorsal scald injury model.

In our laboratory, we have extensively studied the effects of PTX on lung injury and inflammation in models of mechanical ventilation $^{15}$ and sepsis ${ }^{16}$. Fletcher et al. ${ }^{17}$, used a single bolus $\left(20 \mathrm{mg} \cdot \mathrm{kg}^{-1}\right)$ and improved survival rates, whereas multiple pentoxifylline injections of the same dose worsened survival rates.

Pulmonary inflammatory conditions and cellular lung injury have been associated with increased protein concentration in that tissue ${ }^{18}$. Our model, also showed an increase in protein concentrations after thermal injury, however this increase was reduced in the PTX-treated burn groups.

Thermal injury of the skin results in local tissue damage and a systemic inflammatory response which is extremely complex, resulting in local burn tissue injury, as well as systemic effects involving organs distant from the burn area itself ${ }^{19}$. Local burn injury activates several proinflammatory cytokines, mostly
TNF-alpha; the increased circulating level is a stronger predictor of cause mortality risk in longitudinal studies of the elderly ${ }^{20}$.

Costantini et al. ${ }^{21}$ have clearly demonstrated the antiinflammatory effects of PTX after thermal injury.

Other anti-inflammatory drugs also seemed to reduce the levels of TNF-alpha after the burns, however, the administration of drugs in these studies was conducted differently than ours. Xu et $a .^{22}$, injected $100 \mathrm{~g} / \mathrm{L}$ omega-3 PUFA $(1 \mathrm{~mL} / \mathrm{kg})$ via tail vein within 5 minutes after burn and continuously injected for 10 days (once a day). They analyzed the serum level of TNF-alpha in 1, 4, 7 and 10 days after burn, and found a significant reduction in all of them. Cevik et $a l .{ }^{23}$, treated adult rats with lycopene (50 $\mathrm{mg} / \mathrm{kg}$ orally) after thermal trauma, and found that despite severe skin scald injury caused a significant elevation in the TNF-alpha, the lycopene treatment reversed these biochemical indices. In our study, the drug was administered in a single dose, six hours after the burn, and this factor in practice is a possible advantage, since most of the time the burned patient takes some time to receive treatment and therefore the drug administration. Our results revealed elevated levels of the cytokine in adult-burned, but in animals. However, in the elderly-burned group these levels were higher and PTX treatment reduced these levels.

Elderly-burned animals presented an increased MDA level when compared with adult animals. The PTX treatment significantly decreased MDA levels in the lungs of both groups. This PTX antilipoperoxidative effect may be explained by its direct free radical property ${ }^{24}$.

Stengle et al. ${ }^{9}$ analyzing mice (8-10 weeks) after burn injury (15\% TBSA) demonstrated that the is a reduction of neutrophils after $24 \mathrm{~h}$ and Nomelline et al. $^{25}$, analyzing mice (222 months), after burn injury (15\% TBSA) demonstrated that age-associated pulmonary congestion may be due to differences in lung endothelial adhesion responses that are compounded by elevated numbers of hyperchemokinetic circulating neutrophils in aged mice.

In our study, the tissue-associated MPO activity was elevated in the lungs $24 \mathrm{~h}$ after burn injury (30\% TBSA) in adults and elderly rats, but more significant in elderly rats. MPO plays an important role in the production of oxidants, which are a potential source of ROS and are considered to be the major effectors in remote organ damage ${ }^{19,26}$. According to our results, treating rats with PTX attenuated the increase in MPO tissue levels of caused by thermal injury with neutrophil degranulation possibly interfering with cell presence assessment. Fang et $a .^{27}$ studies using MPO analyses after $12 \mathrm{~h}$ of thermal injury demonstrated the increase of MOP activity in rat lungs. 


\section{Conclusions}

Thermal injury induces oxidative and inflammatory organ damage distant from the original wound. Burn-induced tissue injury in lung is dependent upon the formation of oxygen radicals and inflammatory mediators. Treatment with PTX reduced the burn-induced distant organ damage.

\section{References}

1. American Burn Association (ABA), 2011. National Burn Repository: 2011 Report.

2. Miller SF, Bessey PQ, Schurr MJ, Browning SM, Jeng JC, Caruso DM, Gomez M, Latenser BA, Lentz CW, Saffle JR, Kagan RJ, Purdue GF, Krichbaum JA. National Burn Repository 2005: a tenyear review. J Burn Care Res. 2006;27:411-36.

3. Herdon DN, Traber DL. Pulmonary circulation and burns and trauma. J Trauma. 1990;30:S41-4.

4. Sadighi Akha AA, Miller RA. Signal transduction in the aging immune system. Curr Opin Immunol. 2005;17:486-91.

5. Plackett TP, Boehmer ED, Faunce DE, Kovacs EJ. Aging and innate immune cells. J. Leukocyte Biol. 2004;76:291-9.

6. Franceschi C, Bonafè M, Valensin S, Olivieri F, De Luca M, Ottaviani E, De Benedictis G. Inflamm-aging. An evolutionary perspective on immunosenescence. Ann NY Acad Sci. 2000;908:244-54.

7. Chen LW, Hwang YC, Wang JS, Chen JS, Hsu CM. Inhibition of nitric oxide synthase reverses the effect of albumin on lung damage in burn. J Am Coll Surg. 2005;200:574-83.

8. Hansbrough JF, Wikström T, Braide M, Tenenhaus M, Rennekampff $\mathrm{OH}$, Kiessig V, Bjursten LM. Neutrophil activation and tissue neutrophil sequestration in a rat model of thermal injury. J Surg Res. 1996;61:17-22.

9. Stengle J, Meyers R, Pyle J, Dries DJ. Neutrophil recruitment following remote scald injury. J Burn Care Rehabil. 1996;17:14-8.

10. Bessler H, Gilgal R, Djaldetti M, Zahavi I. Effect of pentoxifylline on the phagocytic activity, cAMP levels, and superoxide anion production by monocytes and polymorphonuclear cells. J Leukocyte Biol. 1986;40:747-54.

11. Lowry OH, Rosebrough NJ, Farr AL, Randall RJ. Protein measurement with the Folin phenol reagent. J Biol Chem. 1951;193:265-75.

12. Yagi K. Lipid peroxides and related radicals in clinical medicine In: Armstrong D, ed. Free radicals in diagnostic medicine. New York: Plenum; 1994. p.1-15.

13. Okhawa H, Ohishi N, Yagi K. Assay for lipid peroxides in animal tissues by thiobarbituric acid reaction. Anal Biochem. 1979;95:3518.

14. Hillegass LM, Griswold DE, Brickson B, Albrightson-Winslow C. Assessment of myeloperoxidase activity in whole rat kidney. J Pharmacol Meth. 1990;24:285-95.

15. Oliveira-Júnior IS, Pinheiro BV, da Silva IDCG, Zollner RL, Beppu OS. Pentoxifylline decreases tumor necrosis factor and interleukinlbeta during high tidal volume. Braz J Med Biol Res. 2003;36:134957.

16. Oliveira-Júnior IS, Oliveira WRS, Cavassani SS, Brunialti MKC, Salomao R. Effects of pentoxifylline on inflammation and lung dysfunction in ventilated septic animals. J Trauma. 2010;68:822-6.

17. Fletcher MA, Mckenna TM, Owens EH and Nadkarni VM. Effects of in vivo pentoxifylline treatment on survival and ex vivo vascular contractility in a rat lipopolysaccharide shock model. Circ Shock.
1992;36:74-80.

18. Nagato A, Silva FL, Silva AR, Bezerra FS, Oliveira ML, Belló-Klein A, Cristovao-Porto L, Santos-Valenca S. Hyperoxia-induced lung injury is dose dependent in Wistar rats. Exp Lung Res. 2009;35:71328.

19. Sener G, Sehirli AO, Satıroglu H, Keyer-Uysal M, Yeğen BC. Melatonin improves oxidative organ damage in a rat model of thermal injury. Burns. 2002;28:419-25.

20. Krabbe KS, Pedersen M, Bruunsgaard H. Inflammatory mediators in the elderly. Exp. Gerontol. 2004;39:687-99.

21. Costantini TW, Peterson CY, Kroll L, Loomis WH, Putnam JG, Wolf P, Eliceiri BP, Baird A, Bansal V, Coimbra R. Burns, inflammation, and intestinal injury: protective effects of an anti-inflammatory resuscitation strategy. J Trauma. 2009;67:1162-8.

22. Wu X, Woodside KJ, Song J, Wolf SE. Burn-induced gut mucosal homeostasis in TCR\% receptor-deficient mice. Shock. 2004;21:527.

23. Cevik O, Oba R, Macit C, Cetinel S, Kaya OT, Sener E, Sener G. Lycopene inhibits caspase- 3 activity and reduces oxidative organ damage in a rat model of thermal injury. Burns. 2012;38:861-71.

24. Dubick MA, Carden SC, Jordan BS, Langlinais PC, Mozingo DW. Indices of antioxidant status in rats subjected to wood smoke inhalation and/or thermal injury. Toxicology. 2002;176:145-57.

25. Nomellini V, Brubaker AL, Mahbub S, Palmer JL, Gomez CR, Kovacs EJ. Dysregulation of neutrophil CXCR2 and pulmonary endothelial icam-1 promotes age-related pulmonary inflammation. Aging Dis. 2012;3:234-47.

26. Starr ME, Ueda J, Yamamoto S, Evers BM, Saito H. The effects of aging on pulmonary oxidative damage, protein nitration, and extracellular superoxide dismutase down-regulation during systemic inflammation. Free Radic Biol Med. 2011;50:371-80.

27. Fang Y, Fu X-J, Gu C, Xu P, Wang Y, Yu W-R, Sun Q, Sun X-J, Yao $M$. Hydrogen-rich saline protects against acute lung injury induced by extensive burn in rat model. J Burn Care Res. 2011;32:e82-91.

\section{Acknowledgments}

The authors wish to thank Professors Manuel Jesus Simões and Helga Cristina Almeida Silva for their technical assistance, Willian Andrew Presada for assistance with translation of article.

\section{Correspondence:}

Itamar Souza de Oliveira-Júnior

Disciplina de Anestesiologia, Dor e Terapia Intensiva

Rua Botucatú, 740

04023-900 São Paulo - SP Brasil

Tel.: (55 11)5576-4268

Fax: (55 11)5576-4322

souza.oliveira@unifesp.br

Received: September 26, 2012

Review: November 28, 2012

Accepted: December 23, 2012

Conflict of interest: none

Financial source: Sao Paulo Research Foundation (FAPESP - 06/608349)

${ }^{1}$ Research performed at Laboratory of Surgery and Laboratory of Histology, Federal University of Sao Paulo (UNIFESP), Brazil. Part of PhD degree thesis. Tutor: Itamar Souza Oliveira-Júnior. 